\title{
ВОЗМОЖНОСТЬ ИСПОЛЬЗОВАНИЯ ПОРОШКА ИЗ ЯГОДНЫХ ВЫЖИМОК КОСТЯНИКИ КАМЕНИСТОЙ В РЕЦЕПТУРАХ МЯСНЫХ РУБЛЕНЫХ ПОЛУФАБРИКАТОВ
}

\author{
D.V. Broshko, N.A. Velichko, E.A. Rygalova
}

\section{THE POSSIBILITY OF USING THE POWDER FROM POMACE BERRY BRAMBLE ROCKY IN THE FORMULATIONS OF MEAT CHOPPED SEMI-FINISHED PRODUCTS}

Брошко Доминик Василь - магистрант каф. технологии консервирования и пищевой биотехнологии Красноярского государственного аграрного университета, г. Красноярск.

E-mail: vena@kgau.ru

Величко Надежда Александровна - д-р техн. наук, проф., зав. каф. технологии консервирования и пищевой биотехнологии Красноярского государственного аграрного университета, г. Красноярск. E-mail: vena@kgau.ru

Рыгалова Елизавета Александровна - канд. техн. наук, доц. каф. технологии консервирования и пищевой биотехнологии Красноярского государственного аграрного университета, г. Красноярск. E-mail: x3x3x@list.ru

Цель исследования - разработка рещептур и оценка потребительских свойств мясных рубленых полуфрабрикатов (котлет) с добавлением порошка из выжимок ягод костяники каменистой. Задачи исследования: разработать реuептурные композиции мясных полусрабрикатов (котлет) с добавлением нового ингредиента порошка из ягодных выжимок костяники каменистой; определить дозировку порошка, обеспечивающую наилучшие органолептические показатели продукта. Исследовано влияние различных дозировок внесения ягодного порошка на органолептические показатели мясных рубленых полуфрабрикатов. Количество вносимого порошка, необходимое для достижения лучших органолептических показателей мясных рубленьх полусрабрикатов (котлет), составило 10 \% взамен мясного фрарша. Проведена дегустационная оценка полученных мясо-растительных изделий. Разработана рецептура мясных рубленых полусрабрикатов с внесением ягодного порошка из вьжимок костяники каменистой. Рассчитана пищевая ценность мясо-растительного продукта. Установлено, что мясо-растительные котлеты с добавлением 10 \% ягодного порошка из выжимок костяники каменистой восполняют 45 \% суточной нормы в белке, на 29 \% - в вита-
Broshko Dominique Vasyl - Magistrate Student, Chair of Technology of Canning and Food Biotechnology, Krasnoyarsk State Agrarian University, Krasnoyarsk.

E-mail: vena@kgau.ru

Velichko Nadezhda Alexandrovna - Dr. Techn. Sci., Prof., Head, Chair of Technology of Canning and Food Biotechnology, Krasnoyarsk State Agrarian University, Krasnoyarsk.

E-mail: vena@kgau.ru

Rygalova Elizaveta Alexandrovna - Cand. Techn. Sci., Assoc. Pof., Chair of Technology of Canning and Food Biotechnology, Krasnoyarsk State Agrarian University, Krasnoyarsk, Krasnoyarsk.

E-mail: x3x3x@list.ru

мине $P$, на $24 \%$ - в витамине $B_{1}$, на $22 \%$ - в жирах, на $19 \%$ - в пищевых волокнах, на $20 \%$ покрывают потребность в минеральном элементе железе, на 10 \% - в калии. Показано, что использование в производстве рубленых мясных полусьабрикатов в качестве ингредиента растительного компонента порошка из ягодных выжимок костяники каменистой является перспективным направлением и дает основание для разработки технологий производства комбинированных мясных полусрабрикатов, способствует расширению их ассортимента, обогащению фозиологически значимыми компонентами, снижению себестоимости продукта.

Ключевые слова: ягодный порошок, выжимки, рецептура, мясо-растительный полуфабрикат, котлеты, органолептические показатели, пищевая ценность.

The research objective was the development of the formulations and the assessment of consumer properties of meat chopped semi-finished products (cutlets) with addition of the powder from the pomace of berries of stone bramble stony. The research problems were to develop the prescription compositions of meat semi-finished products (cutlets) with addition of new ingredient - the powder from a berry pomace of 
stone bramble stony; to define the powder dosage providing the best organoleptic indicators of the product. The influence of various dosages of introduction of berry powder on organoleptic indicators of meat chopped semi-finished products was investigated. The amount of brought powder necessary for the achievement of the best organoleptic indicators of meat chopped semi-finished products (cutlets) made $10 \%$ instead of mincemeat. The tasting assessment of received meat and cereal products was carried out. The compounding of meat chopped semi-finished products with introduction of berry powder from the pomace of stone bramble stony was developed. The nutrition value of meat and vegetable product was calculated. It was established that meat and vegetable cutlets with addition of $10 \%$ of berry powder from the pomace of stone bramble stony fill $45 \%$ of daily norm in protein, for $29 \%$ - in vitamin $P$, for $24 \%$ - in $B_{1}$ vitamin, for $22 \%$ - in fats, for $19 \%$ - in food fibers, for $20 \%$ satisfying the need for mineral element iron, for $10 \%$ - in potassium. It was shown that using in production of chopped meat semi-finished products as ingredient of vegetable component of powder from a berry pomace of stone bramble stony was perspective direction and gave the grounds for the development of production technologies of combined meat semi-finished products, promoted the expansion of their range, the enrichment by physiologically significant components and the decrease in prime cost of the product.

Keywords: berry powder, pomaces, formulation, meat and vegetable semi-finished product, cutlets, organoleptic indicators, nutrition value.

Введение. Производство мясных полусрабрикатов является одним из наиболее развивающихся направлений в мясной промышленности, потребление их с каждым годом увеличивается [1].

Рубленые мясные полуфабрикаты - это изделия, максимально подготовленные для термической обработки, они являются продуктами высокой степени готовности, что в современных условиях делает их удобной и востребованной формой для потребителя.

Приоритетное значение приобретает разработка рецептур и технологий новых комбинированных полуфабрикатов с высокой биологической ценностью, содержащих белки животного и растительного происхождения [2]. Возрастающая потребность в таких полуфабрикатах и готовых блюдах стимулирует производителей к увеличению объемов производства и расширению ассортимента этой продукции, позволяет придать продукту различные вкусовые оттенки, лечебнопрофилактические свойства, улучшить технологические свойства фрарша, повысить биологическую и пищевую ценность продукта [3-5].

Известно применение различных растительных компонентов в рецептуры мясных полуфабрикатов, таких как соевый изолят, бобовые и зерновые культуры, различные виды клетчаток, порошок топинамбура, капуста брокколи, кукурузная мука и др. [6-10].

Эти компоненты являются источником биологически активных веществ и пищевых волокон, способствуют повышению сопротивляемости организма человека вредному воздействию окружающей среды. Применение порошка из ягодных выжимок костяники каменистой в литературных источниках не отражено.

Цель исследования. Разработка рецептур и оценка потребительских свойств мясных рубленых полуфрабрикатов (котлет) с добавлением порошка из выжимок ягод костяники каменистой.

Задачи исследования: разработать рецептурные композиции мясных полуфабрикатов (котлет) с добавлением нового ингредиента порошка из ягодных выжимок костяники каменистой; определить дозировку порошка, обеспечивающую наилучшие органолептические показатели продукта.

Объекты и методы исследования. Объектом исследования были котлеты мясорастительные с добавлением порошка из ягодных выжимок костяники каменистой. Порошок из ягодных выжимок костяники каменистой был получен в научно-исследовательской лаборатории кафредры технологии консервирования и пищевой биотехнологии Красноярского государственного аграрного университета [11]. Котлеты приготовлены с использованием говяжьего и свиного фарша. Оценка органолептических показателей готовых изделий проводилась согласно ГОСТ 4288, ГОСТ 9959-2015. Дегустационную оценку качества полученных изделий проводили по внешнему виду, цвету, вкусу, аромату, консистенции, общую оценку качества - по 5-балльной шкале.

Результаты и их обсуждение. Порошок из ягодных выжимок костяники каменистой вводили в фрарш при замене мясного сырья в количестве $5,10,15 \%$. Варианты рецептур мясных рубленых полуфабрикатов (котлет с добавлением нового ингредиента - порошка из выжимок ягод костяники каменистой) приведены в таблице 1. 
Рецептуры мясных рубленых полуфабрикатов (котлет) с добавлением порошка из выжимок ягод костяники каменистой, кг на 100 кг

\begin{tabular}{|l|c|c|c|c|}
\hline \multirow{2}{*}{ Сырье } & \multirow{2}{*}{$\begin{array}{c}\text { Контрольный } \\
\text { образец }\end{array}$} & \multicolumn{3}{|c|}{ Дозировка ягодного порошка, \% } \\
\cline { 3 - 5 } & 35 & 30 & 25 & 15 \\
\hline Свинина жилованная & 35 & 27 & 25 & 23 \\
\hline Говядина жилованная & - & 5 & 10 & 15 \\
\hline Порошок ягодных выжимок & 12 & 12 & 12 & 12 \\
\hline Хлеб пшеничный & 2 & 2 & 2 & 2 \\
\hline Яйца куриные или меланж & - & 8 & 10 & 12 \\
\hline Вода для гидратации & 3 & 3 & 3 & 3 \\
\hline Лук репчатый & 10 & 10 & 10 & 10 \\
\hline Вода питьевая & 1,9 & 1,9 & 1,9 & 1,9 \\
\hline Сухари панировочные & 1 & 1 & 1 & 1 \\
\hline Соль поваренная пищевая & 0,1 & 0,1 & 0,1 & 0,1 \\
\hline Перец черный молотый & & & & \\
\hline
\end{tabular}

Котлеты формовали, обжаривали и определяли органолептические показатели готовых изделий.

Органолептические показатели мясных рубленых полусрабрикатов (котлет) с добавлением растительного компонента - порошка ягод костяники каменистой - представлены в таблице 2.

Результаты дегустационной оценки мясного рубленого полуфабриката с добавлением ягод- ного порошка из выжимок костяники каменистой представлены на рисунке 1.

По результатам дегустационной оценки наибольшее количество баллов набрал образец с добавлением 10 \% ягодного порошка из выжимок костяники каменистой.

Пищевая ценность контрольного и опытного образцов приведена на рисунке 2.

Таблица 2

Органолептическая оценка котлет с порошком из ягодных выжимок костяники каменистой

\begin{tabular}{|l|l|}
\hline \multicolumn{1}{|c|}{ Показатель } & \multicolumn{1}{|c|}{ Полученные результаты } \\
\hline Внешний вид & $\begin{array}{l}\text { Сформованная котлетная масса округло-овальной формы, поверхность } \\
\text { без разорванных и ломаных краев. }\end{array}$ \\
\hline Консистенция & $\begin{array}{l}\text { В сыром виде - вязкопластичная (для охлажденных) или твердая (для } \\
\text { замороженных полуфабрикатов); в горячем виде - нежная, сочная, со- } \\
\text { ответствующая консистенции жареных котлет }\end{array}$ \\
\hline Вид фрарша на разрезе & $\begin{array}{l}\text { Фарш розового цвета, равномерно перемешан, с видимыми жировыми } \\
\text { включениями }\end{array}$ \\
\hline Запах и вкус & $\begin{array}{l}\text { В сыром виде - свойственные доброкачественному сырью; в жареном - } \\
\text { свойственные жареному продукту, без посторонних запаха и привкуса }\end{array}$ \\
\hline
\end{tabular}




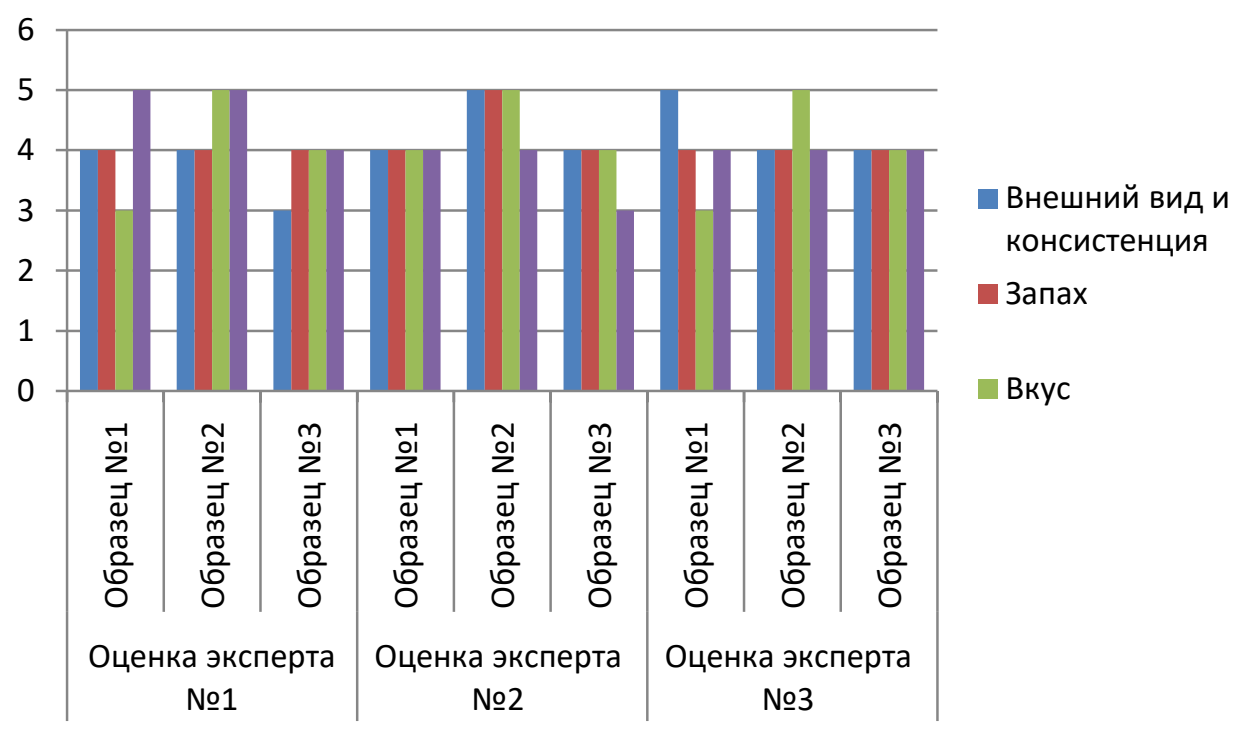

Puс. 1. Дегустационная оценка мясного рубленого полусрабриката с добавлением ягодного порошка из выжимок костяники каменистой

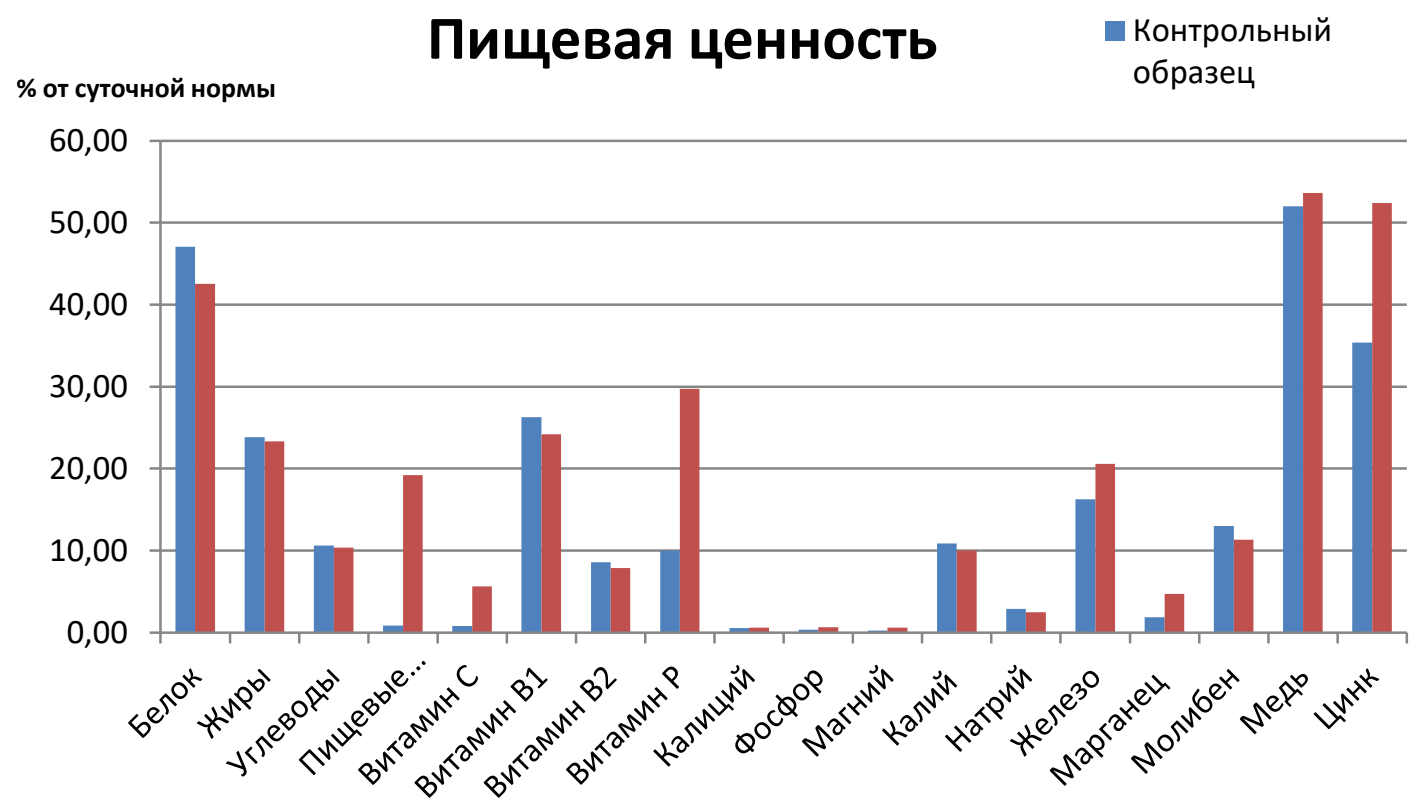

Puс. 2. Пищевая ценность контрольного и опьтного образцов

Было установлено, что мясо-растительные котлеты с добавлением ягодного порошка из выжимок костяники каменистой восполняют $45 \%$ суточной нормы в белке, на 29 \% в витамине Р, на $24 \%$ в витамине $\mathrm{B}_{1}$, на $22 \%$ в жирах, на $19 \%$ в пищевых волокнах, на $20 \%$ покрывают потребность в минеральном элементе железе, на $10 \%$ в калии.
Выводы. Определена дозировка ягодного порошка из выжимок костяники каменистой, обеспечивающая продукту наилучшие органолептические показатели (10 \% взамен мясного сырья). Рассчитана пищевая ценность исследуемых образцов. Установлено, что мясорастительные котлеты с добавлением $10 \%$ ягодного порошка из выжимок костяники каме- 
нистой восполняют $45 \%$ суточной нормы в белке, на $29 \%$ в витамине Р, на $24 \%$ в витамине $\mathrm{B}_{1}$, на $22 \%$ в жирах, на 19 \% в пищевых волокнах, на $20 \%$ покрывают потребность в минеральном элементе железе, на 10 \% в калии.

Использование в производстве рубленых мясных полуфабрикатов в качестве ингредиента растительного компонента порошка из ягодных выжимок костяники каменистой является перспективным направленим и дает основание для разработки технологий производства комбинированных мясных полуфабрикатов, способствует расширению их ассортимента, обогащению физиологически значимими компонентами.

\section{Литература}

1. Анализ состояния и перспективы развития производства мясных полусрабрикатов / Д.Е. Гутник, А.Н. Захаров, М.Н. Смирнов [и др.] // Все о мясе. - 2006. - № 2. - С. 36-39.

2. Курчаева Е.Е., Кицук С.В. Использование растительного и животного сырья в производстве мясных изделий функционального назначения // Известия вузов. Пищевые технологии. - 2012. - № 2. - С. 55-56.

3. Денисович Ю.Ю., Борозда А.В. Перспективы производства мясных полуфабрикатов функционального назначения // Инновационному развитию АПК и аграрному образованию - научное обеспечение: мат-лы Всерос. науч.-практ. конф.: в 3 т. Т. 3 / ФГБОУ ВПО Ижевская ГСХА. - Ижевск, 2012. C. 221.

4. Борисенко Л.А., Брацихин А.А., Борисенко А.А. [и др.]. Новые виды мясорастительных полуфабрикатов на основе злаковых культур // Пищевая промышленность. 2009. - № 10. - С. 16-17.

5. Коновалов К.Л. Растительные ингредиенты в производстве мясных продуктов // Пищевая промышленность. - 2006. - № 4. С. 68-69.

6. Ахмедова Т.П. Использование пищевых волокон для обогащения пищевых продуктов // Актуальные проблемы качества и безопасности потребительских товаров: мат-лы Всерос. заоч. науч. конф. молодых ученых. - Орел: Изд-во ОрелГИЭТ, 2012. c. 18-22.
7. Вайтанис М.A. Обогащение котлетного фарша растительным сырьем // Ползуновский вестник. - 2012. - № 2/2. - С. 217-220.

8. Зайцева Т.Н., Рябова В.Ф., Курочкина Т.И. Обогащение мясных рубленых полуфабрикатов растительными компонентами // Продовольственная безопасность: научное, кадровое и информационное обеспечение: мат-лы Междунар. конф. - Воронеж, 2014. - C. 414-417.

9. Зинина О.В. Обзор разработок комбинированных рубленых полусабрикатов // Молодой ученый. - 2015. - № 21. - С. 165-168.

10. Величко, Н.А., Машанов А.И., Буянова И.В. Возможность использования капусты брокколи для обогащения мясных рубленых полуфабрикатов // Вестник КрасГАУ. - 2018. № 3. - С. 160-164.

11. Гринюк, О.Ю., Величко Н.А., Рыгалова Е.А. Использование выжимок RÚBUS SAXÁTILIS L. в хлебобулочных изделиях // Вестник КрасГАУ. - 2019. - № 5. - С. 143-149.

\section{Literatura}

1. Analiz sostoyaniya i perspektivy razvitiya proizvodstva myasnyh polufabrikatov / D.E. Gutnik, A.N. Zaharov, M.N. Smirnov [i dr.] // Vse o myase. - 2006. - № 2. - S. 36-39.

2. Kurchaeva E.E., Kicuk S.V. Ispol'zovanie rastitel'nogo i zhivotnogo syr'ya $v$ proizvodstve myasnyh izdelij funkcional'nogo naznacheniya // Izvestiya vuzov. Pishchevye tekhnologii. - 2012. - № 2. - S. 55-56.

3. Denisovich Yu.Yu., Borozda A.V. Perspektivy proizvodstva myasnyh polufabrikatov funkcional'nogo naznacheniya // Innovacionnomu razvitiyu APK i agrarnomu obrazovaniyu - nauchnoe obespechenie: mat-ly Vseros. nauch.-prakt. konf.: $\vee 3$ t. T. $3 /$ FGBOU VPO Izhevskaya GSKHA. - Izhevsk, 2012. - S. 221.

4. Borisenko L.A., Bracihin A.A., Borisenko A.A. [i dr.]. Novye vidy myasorastitel'nyh polufabrikatov na osnove zlakovyh kul'tur // Pishchevaya promyshlennost'. - 2009. № 10. - S. 16-17.

5. Konovalov K.L. Rastitel'nye ingredienty $\mathrm{v}$ proizvodstve myasnyh produktov // Pishche- 
vaya promyshlennost'. - 2006. - № 4. S. 68-69.

6. Ahmedova T.P. Ispol'zovanie pishchevyh volokon dlya obogashcheniya pishchevyh produktov // Aktual'nye problemy kachestva i bezopasnosti potrebitel'skih tovarov: mat-ly Vseros. zaoch. nauch. konf. molodyh uchenyh. - Orel: Izd-vo OrelGIET, 2012. - S. 18-22.

7. Vajtanis M.A. Obogashchenie kotletnogo farsha rastitel'nym syr'em // Polzunovskij vestnik. - 2012. - № 2/2. - S. 217-220.

8. Zajceva T.N., Ryabova V.F., Kurochkina T.I. Obogashchenie myasnyh rublenyh polufabrikatov rastitel'nymi komponentami // Prodovol'stvennaya bezopasnost': nauchnoe, kadrovoe i informacionnoe obespechenie: mat-ly Mezhdunar. konf. - Voronezh, 2014. S. 414-417.

9. Zinina O.V. Obzor razrabotok kombinirovannyh rublenyh polufabrikatov // Molodoj uchenyj. - 2015. - № 21. - S. 165-168.

10. Velichko, N.A., Mashanov A.I., Buyanova I.V. Vozmozhnost' ispol'zovaniya kapusty brokkoli dlya obogashcheniya myasnyh rublenyh polufabrikatov // Vestnik KrasGAU. - 2018. № 3. - S. 160-164.

11. Grinyuk O.Yu., Velichko N.A., Rygalova E.A. Ispol'zovanie vyzhimok RÚBUS SAXÁTILIS L. v hlebobulochnyh izdeliyah // Vestnik KrasGAU. - 2019. - № 5. - S. 143-149. 